\title{
Blood Courses Through Veins
}

\author{
Nancy Viva Davis Halifax
}

Nancy Viva Davis Halifax s'intéresse au corps, à la vulnérabilité, à ce que le langage ne peut pas contenir, et à la paix. Dans une langue nuancée, elle propose ici une méditation sur le sang, traversant jour et nuit, terre et paradis. On lit ici ce qui écrit l'intérieur, tranche les mots de la chair, et inscrit la mortalité par le biais d'une profonde coupure.

Blood courses through veins

bays at moon

white muscle

a brocade for its her clothed orbit.

Blood muscles her celestial body

along a gravitational path

accelerating toward their aphelion

and cracks leaking incarnadine night.

\section{II}

In the morning she writes

Inside any animal

blood is a fluid bodily tissue.

Her pen, a rosy nail, leaks its blue blood onto her page.

It's a transport medium

carrying hormones, debris, oxygen.

Her mouth closes

uncalculated she nips her interior 


\section{III}

Blood keeps pace with every footstep

thunders down stairs

strides through this split being

and pours into the world.

through every door

pours into the world.

\section{IV}

Thoughts course

through these veins

one deep cut and

the earth will rise to meet her. 